Mario Enaudi

Center for

No. $1-10$

Intemational

Studies

Parties and Issues in Francophone West Africa: Towards a Theory of Non-Mobilization

J a imie Bleck and Nicolas van de Walle April 2010 
To view past working papers and guidelines for submission, please visit the Mario Einaudi Center for International Studies Working Paper Series webpage at: http://www.einaudi.cornell.edu/initiatives/working.asp. For more information please contact Dr. Heike Michelsen, 170 Uris Hall, Tel: 607.255 .8926 , hm75@cornell.edu. 


\title{
Parties and Issues in Francophone West Africa: Towards a Theory of Non-Mobilization
}

\author{
Jaimie Bleck and Nicolas van de Walle, Cornell University
}

\begin{abstract}
This paper builds a theory about electoral discourse in Africa and the salience of political issues since the return of competitive elections in the early 1990s, based on empirical materials from recent elections in Mali, Mauritania, Niger, Benin, Burkina Faso, and Senegal, six roughly similar semi-democratic francophone states in West Africa, which have conducted a least one reasonably free and fair election since the early 1990s. Drawing on content analysis from newspapers, the electronic press, party websites, as well as interviews and secondary sources on elections in these countries, we formulate two empirical arguments; first, issues do in fact captivate and potentially mobilize African voters. Our survey of the subregion suggests that politics is more substantive than generally credited. Second, however, we argue that political parties in the subregion fail to mobilize citizens along many of these issues, for two primary reasons. First, we hypothesize that the shared values and identities of political actors emerging during third wave transitions in the region shaped conceptions of what constitutes democratic politics. For the most part, the world view of Francophone, secular, elites have come to dominate political discourse, restricting the types of issues that could be incorporated into formal politics. Secondly, we employ the concept of issue-ownership to explain why opposition parties have difficulty mobilizing voters with programmatic rhetoric, and shy away from other issues, despite their vote-mobilizing potential.
\end{abstract}

\section{About the Authors}

Jaimie Bleck is a PhD Candidate in the Department of Government at Cornell University. As a Boren Fellow, she completed eleven months of fieldwork in Mali including a survey of 1000 households. Her dissertation project explores the impact of citizens' experiences with different types of education providers, religious and secular, on political knowledge, political trust, and political participation. Before beginning graduate school, Bleck worked for Winrock International as a Program Assistant on USAID's Africa Education Initiative in Central and Southern Africa.

Nicolas van de Walle (Ph.D. Princeton University, 1990) is Professor in Cornell's Department of Government. He is also a Non-Resident Fellow at the Center for Global Development. He has published widely on democratization issues as well as on the politics of economic reform and on the effectiveness of foreign aid, with special focus on Africa. In addition, van de Walle has worked extensively as a consultant for a variety of international and multilateral organizations, including the World Bank, USAID, and UNDP. From 2004 to 2008 he was Director of Cornell's Mario Einaudi Center for International Studies and Associate Dean for International Studies, College of Arts and Sciences.

\section{Contact Information}

Jaimie Bleck, Department of Government, Cornell University, 214 White Hall, Ithaca NY 14853, Email: jb462@cornell.edu.

Nicolas van de Walle, Professor, Department of Government, Cornell University, 206 White Hall, Ithaca NY 14853, Email: nv38@cornell.edu. 



\section{Parties and Issues in Francophone West Africa: Towards a Theory of Non- Mobilization $^{1}$}

\section{Introduction}

Reforming Mali's national Family Code has long been on the agenda of western donors, women's associations and NGOs in Bamako. On 3 August 2009, the Malian Assembly passed the law with a vote of 117 for the bill, five against, and four abstentions. Its statutes establish a legal age of marriage, regulate inheritance, and require statesanctioned marriage. Deputies raised few objections about the more than 1,100 articles in the code. Opposition parties had not included the Family Code in their party platforms or talking points. They were apparently not prepared for the massive opposition to the Code that soon erupted. On 9 August, the head of the High Council on Islam, convened a meeting attended by 2,000 people at Bamako's "Grande Mosque." The following weekend, approximately 10,000 protesters took to the streets in one of the country's biggest public demonstrations since democratization in the early 1990s. On 22 August, the first day of Ramadan, Islamic associations organized a rally of some 50,000 people, which filled the national soccer stadium and spilled out into the streets. In the face of this spectacle, the major political parties remained silent. ${ }^{2}$

Why had no political party sought to mobilize political support on the basis of the apparently widespread opposition to the new family code? This paper examines the problematic relationship between political parties and issues in West Africa. A longstanding conventional wisdom among scholars argues that contemporary electoral politics in Africa lack substantive issues. The recent literature suggests two distinct arguments in this vein. On the one hand, party competition in the region is said to be about personalities and the delivery of material benefits to one's ethnic group. A large literature emphasizes the role of ethnicity in shaping party systems in the region. ${ }^{3}$ Some scholars have compared elections in the region to a census on cultural identity, in which a voter's ethnicity or race largely explains voting, and parties serve to register these ethno-racial blocs, rather than mobilize voters around substantive issues. ${ }^{4} \mathrm{~A}$ recent paper by Bratton and Kimenyi suggests a more sophisticated approach in which parties' ethnic appeals coexist with issue-based appeals to shape voting decisions, but theirs is a minority view. ${ }^{5}$ For their part, a number of country case studies have described elections as largely devoid of debate, and consisting largely of folkloric events in which

\footnotetext{
${ }^{1}$ We would like to thank Isaline Bergamaschi, Dennis Galvan, Mamoudou Gazibo, John Gerring, Michelle Kuenzi, Cédric Mayrargue, Birame Ndao, Danielle Resnick, Daniel Smith, and Leonardo Villalon for their useful comments. All remaining flaws are, of course, our own.

2 For reporting on the vote and protests: Diallo, A. 'Assemblée nationale"'(L'Essor August 5, 2009); Coulibaly et al, 'Mahmoud Dicko'(Le Republicain August 11, 2009); and Coulibaly, B. 'Code des personnes et de la famille' (Soir de Bamako, August 31, 2009)

${ }^{3}$ Mozaffar et al, 'Electoral Institutions',; Erdmann, 'Party Research':

${ }^{4}$ Ferree, 'Explaining South Africa's Racial Census'; Ottaway, 'Ethnic Politics in Africa'; Chabal and Daloz, Africa Works

${ }^{5}$ 'Voting in Kenya'
} 
candidates and their parties attract voters through various material promises as well as small amounts of cash, t-shirts and bags of rice. ${ }^{6}$ Others, finally, have largely reduced Africa elections to vote buying and various violent threats. ${ }^{7}$

On the other hand, other observers have noted that explicitly programmatic parties have not performed well in the region. ${ }^{8}$ There are no successful labor parties in the region defending the interests of an organized working class. Parties with names suggesting support for the working class or for socialist ideas are common, of course, but their political rhetoric is rarely meaningfully programmatic. In contrast to both Europe and Latin America, no Christian Democracy tradition exists in Sub Saharan Africa, despite the large proportion of voters who are regular members of various Christian churches.

Accounts of politics in French West Africa provide many examples of vote buying and various kinds of handouts to individuals and to local football teams, by the candidates of different parties, whose policy platforms are vague and anodyne. African elections generally fail to include political debate about the macro-economic policy negotiations many governments are undertaking with the International Monetary Fund. Just as clearly, African political parties are not easily placed on a traditional left-right spectrum. The policy differences which define them rarely appear to be about ideological issues relating to the economy or the role of the state within the economy. One cannot link the party systems across the region to the kind of historical cleavages that helped to define political parties in Western Europe early in its own democratic history as memorably analyzed by Lipset and Rokkan, and which have proved remarkably resilient, even as new issues have come dominate and inspire the formation of new parties. ${ }^{9}$

This paper builds a theory about electoral discourse in Africa and the salience of political issues since the return of competitive elections in the early 1990s, based on empirical materials from recent elections in Mali, Mauritania, Niger, Benin, Burkina Faso, and Senegal, six roughly similar semi-democratic francophone states in West Africa, which have conducted a least one reasonably free and fair election since the early $1990 \mathrm{~s} .{ }^{10}$ All six have similar presidential constitutions and electoral systems, so that institutional

\footnotetext{
${ }^{6}$ Banegas, 'Marchandisation du vote', ;Bierschenck, 'The local appropriation of democracy'; Marcus and Ratsimbaharison, 'Political Parties in Madagascar'

${ }^{7}$ Collier, Wars, Guns, and Votes; Bratton, 'Vote buying and violence in Nigerian election campaigns'; Basedau et al, Votes, Money and Violence; But see Buijtenhuijs for an early contrary view, "Les Partis Politiques Africains';

${ }^{8}$ van de Walle and Butler, Political Parties and Party Systems in Africa's Illiberal Democracies; Salih, African Political Parties

${ }^{9}$ Erdmann, 'Party Research'; Dalton, Citizen Politics in Western Democracies; Lipset and Rokkan, 'Cleavage Structures, Party Systems, and Voter Alignments'

${ }^{10}$ Each country achieved a Freedom House rating of four or less on political and civil liberties at least once since 1991. Cote d'Ivoire, Guinea, Chad, and Togo failed to achieve this minimum threshold and are excluded from our analysis.
} 
factors can be viewed as constant in the analysis that follows. Drawing on content analysis from newspapers, the electronic press, party websites, as well as interviews and secondary sources on elections in these countries, we formulate two empirical arguments; first, as suggested by the anecdote above regarding the Family Code, issues do in fact captivate and potentially mobilize African voters. Our survey of the subregion suggests that politics is more substantive than generally credited.

Second, however, we argue that political parties in the subregion fail to mobilize citizens along most of these issues, for two primary reasons. First, we hypothesize that the shared values and identities of political actors emerging during third wave transitions in the region shaped conceptions of what constitutes democratic politics. For the most part, the world view of Francophone, secular, elites have come to dominate political discourse, restricting the types of issues that could be incorporated into formal politics. Secondly, we employ the concept of issue-ownership to explain why opposition parties have difficulty mobilizing voters with programmatic rhetoric. West African parties are generally young, inexperienced, share similar backgrounds, and generally lack distinct constituencies of support, making it difficult for them to draw on reputational attachments to specific issues. Therefore, we argue that opposition parties across the subregion are most likely to mobilize on similar issues, which are drawn from a common vocabulary of democratic politics and are perceived to be "opposition issues."

The first section of the paper explores the subregion's political and historical context that has shaped the worldview of most opposition parties. The following section challenges the notion of African parties as uniquely exotic, clientelist machines that lack an interest in issues or substance, by showing that in West Africa, as elsewhere, rhetoric and ritual are related to substantive political debate. It highlights shared norms of democratic politics hidden within the rhetoric and ritual of West African politics. The third section adapts the theory of issue ownership from American politics to the context of African politics. Based on our data from francophone West Africa, we classify issues as opposition-owned, incumbent-owned, or contentious, in order to explain the likelihood that the opposition will engage them. In the final section, we reflect on the possibilities for opposition mobilization along substantive issues and the predicted relevance of the theory in other regions of the continent.

\section{The Context of Party Formation in West Africa}

The six countries on which on which we focus share a number of characteristics. They share semi-presidential constitutional systems, as well as two round-majority systems for the presidency, and all but Mali and Mauritania have a single round voting system for legislative elections. Their experience with democracy is recent and uneven. Francophone West African transitions to democracy in the early 1990s began with national conferences in Benin, Niger, and Mali in 1991, and the departure of incumbent presidents. In our other countries, Burkina Faso, Mauritania and Senegal, incumbents clung to power, but governments made significant subsequent democratic adjustments to their constitutions. In all six countries, nonetheless, democratic consolidation 
remains uncertain; in particular, incumbents continue to derive significant material, organizational and legitimacy advantages from controlling the state apparatus.

Political parties in Francophone West Africa have been shaped by five contextual factors. First, although it is possible to discern links to the earlier party systems that existed briefly around independence, most contemporary parties emerged in the aftermath of democratization in the early 1990s, following several decades of single party dominance. As a result, a surprisingly large proportion of the leading opposition politicians had previously belonged to the single party, and or served in its governments in the 1970s and 1980s. Thus, opposition parties in the sub-region are for the most part quite young, and are constituted by similarly socialized politicians.

Second, and relatedly, political parties have been created and managed by educated, westernized urban elites. Their political values are typically shaped by those prevailing in the donor and NGO community. ${ }^{11}$ Members of the opposition can be viewed as part of an educated, cosmopolitan "classe politique," with overseas experiences that appear distinct from the poor, illiterate, and god-fearing overwhelming majority of citizens. ${ }^{12}$ While similar rifts between elite politicians and the masses exist in most countries, low levels of urbanization and economic development in the region exacerbate this disjuncture. All six countries have 2009 UNDP Human Development Indicator rankings in the bottom quintile - ranging from Mauritania ranked $154^{\text {th }}$ to Niger ranked last of 182 countries. $^{13}$

Third, the countries in the sub-region are characterized by high levels of foreign aid dependence. During the last two decades, Western donors have played an increasingly intrusive political and economic role in these regimes, as the emergence of electoral politics coincided with donor-supported structural adjustment and privatization programs as well as the Millennium Development Campaign to increase access to social services and improve human capital. Typically, well over half of the investment budget is provided by foreign aid, while perhaps as much as two thirds of social service provision is assured by aid agencies and foreign NGOs. Inevitably, this aid dependence affects the party system. To be sure, donors have provided direct assistance to opposition politicians, in the context of various civic education programs, scholarships, study tours of western countries, and various other linkages to western embassies. But in addition, the civil society fabric from which some opposition politicians emerged is closely integrated into the aid system. Most major civic associations receive international support. Donors are typically the most important private employer in the capital, offering among the best remunerated positions available to many of the most highly educated local professionals.

\footnotetext{
${ }^{11}$ Daloz, Le (Non-) Renouvellement Des Elites en Afrique Subsaharienne

${ }^{12}$ Sears, Deepening Democracy; Idrissa, The Invention of Order; Villalon and Idrissa, 2005;

${ }^{13}$ http://hdr.undp.org/en/media/HDR_2009_EN_Summary.pdf
} 
Fourth, political parties are shaped by the sub-region's common Franco-phone heritage. In particular, political elites share a strong common secular tradition, which associates modernity with a secular public sphere. The banning of religious and ethnic parties in all six countries is one direct result of this heritage. ${ }^{14}$ Religious interest groups that have attempted to integrate Islam into national institutions and legalize religious political parties have consistently been defeated by a remarkably united political class. ${ }^{15}$ Despite being an avowedly theocratic state, Mauritania did not allow Islamic parties to register in 1991, and the reformist Party for Democratic Convergence (PCD) was not allowed in 2004 or 2005. In Senegal, where the Mourides have long enjoyed real political influence, some political parties are led by Imams (for instance, the Imam Mbaye Niang, Member of Parliament and Secretary General of MRDS) or by influent members of various Islamic Brotherhoods (PVD of Serigne Modou Kara Mbacke, or the MRS of Serigne Moustapha Sy, and FAP of Ahmed Khalifa Niasse). However, the participation of imams in political parties is quickly criticized by the press and other parties, as divisive and a threat to the secular nature of the state. Some opposition parties have opposed what they view as President Wade's willingness to subvert the secular tradition of the state and grant growing political influence to the Mourides. ${ }^{16}$

These countries also share legal restrictions on other "particularistic" parties (ethnic or regional), given the longstanding fear that electoral politics might exacerbate these cultural divisions and lead to political instability and violence. ${ }^{17}$ The degree to which these rules have been prohibitive varies: Burkina Faso, Niger Mali, and Senegal boast much weaker ethnic and regional party cleavages than other countries in Africa. ${ }^{18}$ However, Benin and Mauritania each have opposition parties with clear regional or ethnic characteristics.

Finally, an important fifth factor that shapes the political rhetoric and strategies of political parties in the sub region is their general lack of popularity and low legitimacy, a striking finding of attitudinal surveys such as the Afrobarometer, ${ }^{19}$ in which citizens have expressed distrust of political parties, and their strong preference for consensual politics over partisanship. ${ }^{20}$ Perhaps these citizens have not yet become accustomed to partisan debate, given the rhetorical emphasis on national unity and consensus during the long era of the single party. In any event, this popular attitude puts added pressure on the opposition, since the incumbent party escapes the worst of this popular censure, in part because people associate it with the government and imbues it with the legitimacy of the state. Incumbents in the region understand this. Politicians including Yayi Boni in

\footnotetext{
${ }^{14}$ Bogaards, 'Electoral Systems'

${ }^{15}$ Villalon and Idrissa, 'Repetitive Breakdowns and a Decade of Experimentation', 32

16 'Les Assises du Sénégal' (http://www.assises-senegal.info)

${ }^{17}$ Bogaards, 'Electoral Systems'; Glickman, Ethnic Conflict and Democratization in Africa

${ }^{18}$ Dunning and Harrison, 'Cross-Cutting Cleavages and Ethnic Voting'; Villalon and Idrissa, 'Repetitive Breakdowns'

${ }^{19}$ Logan, 'The Trust Gap'; Little and Logan, 'The Quality of Democracy and Governance in Africa'

${ }^{20}$ Logan, 'The Trust Gap,' Sears, Deepening Democracy;
} 
Benin or Amadou Toumani Touré in Mali have won campaigns running as independents and advocating national consensus. Once in power, these same politicians have criticized partisanship, as a way to manage opposition. Thus, it seems plausible that opposition parties engage in at least some self-censorship in their rhetoric.

We argue that these five factors shape the world view and discourse of politicians in the region. It has served to stabilize democratic politics, which is now widely perceived as the only legitimate form of governance among these elites. ${ }^{21}$ More importantly, this historical context helped shape a hegemony of ideas about "democratic politics" that continues to shape parties' agendas, and restricts the choice-set of political issues that dominate the rhetoric of parties in recent elections. As argued below, these factors also help to explain the inattention of opposition parties to the pressing concerns of nonelites. Opposition politics has constituted a game played by secular elites who were tasked with balancing populations' urgent demands for development with meager national budgets and the concerns of donors, challenging incumbents' grasp on power without dividing the population, and attracting aid to help fund development projects.

\section{Rhetoric and Ritual in West African Elections}

Political rhetoric and ritual in the African context is often portrayed as unimaginative, non-programmatic, and largely focused on fueling clientelist relationships. Clearly, few African elections have included sophisticated debates about macro-economic policy or education. it is often difficult to discern the substantive policy relevance of such rituals of West African elections such as politicians sponsoring soccer games, or the distribution of bags of rice or t-shirts at rallies at which there is very little discussion of the party's policy platform.

However, West African politics should not be held to an unrealistic standard. Empty rhetoric and populist ritual is common across all democracies. In the US, observers note the posturing by American politicians regarding their unbridled patriotism (in the 2008 election, candidate Obama's initial reluctance to wear a flag pin on his lapel was criticized as suggestive of his inadequate patriotism), or their attachment to family values and the rural way of life. Visiting county fairs, eating regional specialties and praising the quality of the local livestock is an inevitable ritual for most national politicians running for office in the OECD. The ritual is viewed as a way for politicians and parties to signal both their recognition of the political power and legitimacy of rural interests, and their support of a policy agenda that will support these rural interests. Rhetoric and ritual do not preclude a substantive understanding of political issues, but represent instead the idiom of electoral practice, the pre-requisite practices through which candidates communicate and appeal to voters, notably about substantive issues.

\footnotetext{
${ }^{21}$ Bratton et al, Public Opinion, Market Reform, and Democratization in Africa.; Little and Logan, 'The Quality of Democracy and Governance in Africa'
} 
West African politics parties' rhetoric and rituals should similarly be understood in the context of their own unique political heritage. Much political rhetoric communicates politicians' attachment to the key values of liberal democracy, on the one hand, and economic development, on the other. The political class has built its own identity around the concept of the secular, republican state. ${ }^{22}$ The recurring rhetorical references to democracy reflect both recent democratization, but also the attachment of politicians themselves to these institutions.

In addition, given the rampant poverty in the region, all politicians and party platforms must invariably express support for rapid economic development. It is easy to be cynical regarding this rhetoric, given the uneven support for economic development by successive governments, but the low level of development prevailing in the region and the evident wish of most of the voters for more rapid economic progress and poverty alleviation probably assures that politicians feel they need to invoke its importance. As a result, most parties in the region have adopted almost identical rhetoric about "good governance" and anti-corruption measures as well as justice, liberty, human rights, and solidarity. We argue that politicians adopt this "development speak", because they have internalized a fundamental value of the political system. ${ }^{23}$ No one can be against democracy or fail to support economic development, much in the same manner that all American politicians choose to adopt an ostentatious patriotism.

Political parties rely on rituals, such as two ubiquitous West African electoral staples, the pre-election soccer games and the candidate country-side tour, that reflect and evoke the central values of democracy and development in the political psyche. The nature of these political rituals is often veiled by clientelism, as they create venues for the public distribution of patronage, but it is important to recognize their political symbolism as well. Parties stage "youth focused" soccer games to express concern for unemployment and the urgency of job creation, education, and greater economic opportunities. These issues concern not just young people, but their parents and families, who are increasingly concerned about job and education prospects for young people as well as the general population who worry about the violent history of youth protests and strikes in recent democratic memory. Soccer games become more than venues to distribute money and resources; they are designed to signal the candidates' commitment to eradicating unemployment and providing opportunities to youth.

Most national level candidates similarly embark on a pre-election tour to visit their future constituencies, in districts far away from the capital. Jourde chronicles the role of presidential tours in Mauritania as a symbolic broadcasting of power and a co-opting theatrical performance, but also as a guarantee to rural populations that the president hears their specific grievances. ${ }^{24}$ The ability to leave the capital to better understand

\footnotetext{
${ }^{22}$ Idrissa, The Invention of Order; Sears, Deepening Democracy

${ }^{23}$ Bierschenk 'Democratization without Development,' 349

24 'The President Is Coming to Visit'
} 
the problems and perspective of the common man is important to rural voters. Candidates' tours emphasize candidates' willingness to listen to demands of rural populations, but also speak to the larger problem of infrastructure. As a candidate embarks on a tour to a remote region, traveling the same lousy roads on which rural populations depend provides a way to demonstrate solidarity with the local populations. Despite the tremendous expense and time involved, presidential candidates all undertake such extensive tours, which appear essential to political legitimacy. ${ }^{25}$

\section{Issue Ownership in the West African Context}

First introduced by John Petrocik, the theory of "issue ownership" posits that parties will focus on issues that they "own," because they have greater credibility as being able to manage and resolve these issues. Parties earn reputations as "owners" of issues over time as parties and candidates' performances on issues is tested. In American politics, parties have "sociologically distinctive constituencies" and the "linkage between a party's issue agenda, and the social characteristics of its supporters is quite strong." ${ }^{26}$ This connection creates a reciprocal effect in which segments of society support parties to promote or protect their interest, while parties advertise these policies to draw supporters form these communities. Parties' attempts at promoting policies in an issue space claimed by another party are eclipsed by the voters' perceptions of parties' reputational issue areas. ${ }^{27}$

African political parties face multiple challenges to earning reputations as "issue owners." Most African parties are less than two decades old and have actually competed only in a small number of electoral campaigns. In addition, political actors share a profile, as urban, educated, Francophone elites, distinct from the rest of the population, which makes it difficult for them to bring specific issue identities to their parties. Lastly, low-income countries of West Africa lack similar structural cleavages one finds in Western Europe, and which have influenced party formation around the world. One sense in which this is clearly true is the size of the working class, at least in its classic sense of unionized low income workers in manufacturing and mining industries, which made the electoral fortunes of the Labor Party in Great Britain, or the Social Democratic Parties in northern Europe. In French West Africa, with its tiny manufacturing sector and capital intensive mining sector, the potential for working class mass parties is low. There is a somewhat larger potential in the white collar public sector, -though these groups represent a miniscule proportion of the labor force, and they have been tightly controlled and or repressed by the state, remaining weakly organized. The absence of strong parties representing class interests in French West

\footnotetext{
${ }^{25}$ Young finds that constituency visits, not private goods, help re-election bids in Zambia and Kenya.

'Is Clientalism at Work'

${ }^{26}$ Petrocik, Benoit, and Hansen, 'Issue Ownership and Presidential Campaigning,'601; Petrocik, John, 'Issue Ownership in Presidential Elections,' 828.

${ }^{27}$ Norpoth and Buchanan. 'Wanted'
} 
Africa can be related to these economic structural differences. The exception to this dilemma may be candidates' abilities to draw on their own regional, ethnic, or professional identities to attract bloc constituencies. ${ }^{28}$ While restrictions on the use of regional or ethnic associations limit parties' abilities to identify as proponents of particular constituencies, parties in Benin, and Mauritania have resorted to ethnoregional electoral appeals.

We identify several clear and predictable patterns in the ownership of political issues in West Africa. We distinguish between issues owned by opposition parties and incumbents, before turning our attention to contentious issues, which we define as issues that resonate with citizens, but falls outside of the realm of imagined politics or are risky for elite actors to pursue, and thus are poorly captured by political parties. Below we illustrate our arguments with examples of each type of issue category.

\section{Opposition Issues}

Opposition parties share a conception of what it means to be in the opposition; parties can activate a common vocabulary of democratic politics and claim agendas and issues that reflect their imagined roles as the opposition, in the historical and social context of West Africa. Opposition parties can offer more credible critiques of incumbent corruption or mismanagement and abuse of constitutional power. As mentioned above, opposition parties can draw on ethnic identities to address minority grievances. We argue that opposition parties will be more likely to embrace "opposition issues" than "incumbent's issues" because they have greater credibility with these issues.

Executive Abuses of Power: Opposition parties, particularly in Mauritania, Senegal, and Niger, focus their discourse on constitutional issues; term limits and other basic "rules of the game" are prominent issues. This reflects the newness of the current regime and the authoritarian legacy, as the incumbent continues to enjoy inordinate political advantages in each of these countries. The rules of democracy appear to have been largely internalized by the citizenry, and opposition complaints about the unfairness of the rule of the game find a receptive audience.

In Senegal, President Wade has sought to strengthen his political power by engineering reforms of the constitution, much to the annoyance of opposition groups. ${ }^{29}$ In anticipation of the 2012 Presidential elections, opposition parties created a coalition to publicize the unfairness of the various incumbency advantages that President Wade exploited. The charges have helped the opposition group to gain traction; in the 2009 elections, they won all the major mayoralties in Senegal except for the Casamance region. In Mauritania, opposition parties formed a coalition to protest the 2008 coup and to boycott the June 2009 elections. The movement gained the support of international actors, which were able to negotiate postponement of the 2009

\footnotetext{
${ }^{28}$ Gazibo, Pour une réhabilitation de l'analyse des partis en Afrique

${ }^{29}$ Thiam, 'Une Constitution'
} 
elections. $^{30}$ In Niger, opposition parties and civil society groups created another coalition to organize popular rallies to protest President Tandja's constitutional "coup d'état."

In Burkina Faso, opposition parties united in response to the 1998 murder o journalist Norbert Zongo who was killed while investigating criminal allegations against the president's brother; they continue to invoke this case for legitimacy. Similarly, opposition groups have rallied around repressive crackdowns on protests, perceived abuses or citizens, and other violent abuses of power.

Corruption: Opposition accusations of the squandering of national budgets and citizens' tax revenue through government incompetence and venality find such a receptive audience that is unsurprising that opposition parties regularly base their campaigns on fights against corruption. The 2004 Pakistani Rice Affair, in which Pakistan gave rice to the government of Niger to sell to create capital for a joint development project, provides an example of these dynamics. The opposition publicized that many of the ministers and MPs pocketed the rice and the profit and president was forced to make many high-ranking officials return the stolen money. As a result some incumbent deputies including the Secretary General of the ruling party were defeated. ${ }^{31}$

In a recent scandal, the opposition publicized President Wade's gift of a suitcase full of money to a departing IMF official. While Wade insists this is a local tradition, the opposition trumpeted the issue to highlight its argument of venality at the core of the Wade administration, drawing favorable media coverage.

Minority Rights: In Mauritania, Messaoud Ould Boulkheir, leader of the People's Progressive Alliance, is the son of former slaves. He ran on human rights, eventually becoming the president of the national assembly with backing from Mauritanians typically excluded from politics. In Benin, each of the four main parties draw heavily on regional constituencies. Though not a formal political party, Northern nomadic groups created the Nigerien Movement for Justice, which blogs about the struggle for greater percentages of uranium revenues to be reinvested in the uranium-producing region. ${ }^{32}$

We anticipate that opposition parties are most likely to mobilize along opposition issues because they can credibly sell themselves as the entities best suited to tackle these particular issues. Incumbent parties cannot make credible claims to oust corruption or executive abuse of power in systems dominated by their own parties.

\footnotetext{
${ }^{30}$ Ciavolella et Fresia, 'Mauritanie, la démocratie, au coup par coup'

${ }^{31}$ Gazibo, 'Niger's 2004 Presidential Elections'.

${ }^{32}$ http://m-n-j.blogspot.com/
} 


\section{Incumbent-owned issues:}

The last two decades of experimenting with democracy has also generated a series of issues that are clearly advantageous to incumbents. Since they manage state resources and diplomatic connections they refer to economic development or foreign relations with authority. For their part, opposition candidates lack credibility to speak about development projects or foreign relations because their capacity in these realms remains untested, and so unsurprisingly, their political rhetoric tends to eschew these themes.

National Security: Incumbents often extol the importance of their leadership in response to security threats. In the Sahelian region, these threats have garnered the attention of a dual audience: domestic constituencies as well as a Western audience eager to find allies in the broader "war on terror" as well as centers of stability in a volatile region. In Mali, Mauritania, and Niger, attacks on military installations and the kidnapping of Westerners as well as bombings in Mauritania in the wake of 9-11, have heightened domestic and international fears of fundamentalist terrorism. These concerns have helped spur the US government to invest over $\$ 500$ million in the region, to provide training for host country militaries so that they could better police the desert.

Governments have framed domestic instability in the more global context of the "war on terror" to fundraise for their national budgets, but also to underscore their indispensable roles in ensuring national stability. In Mauritania, President Taya and President Aziz have both tried to raise public fear of foreign extremists making their way into the government. ${ }^{33}$

We observe a related phenomenon in response to the threat of regional insecurity. As thousands of Burkinabe fled the war in Cote d'Ivoire, President Compaoré fostered an image as a "defender of national interest," which helped to earn an $80 \%$ victory in his controversial third term elections. ${ }^{34}$ In this case as well, incumbents find national security rhetoric to be an ideal way in which to appear statesman-like and above the partisan fray.

Development: Incumbents' access to government rents and international donors also adds to their credibility to their reputation around development issues. These West African economies have grown over the last ten years, and elected officials are eager to acknowledge the progress as their own. Reelection campaign slogans throughout the region often ask voters to allow incumbents to "finish the work they started." Niger's president Tandja used this rationale as a justification for his referendum to hold onto power, beyond his allotted two terms. Similarly, in their re-election campaigns

\footnotetext{
${ }^{33}$ Ciavello and Fresia, 'Entre Démocratisation et coups d'état','10; Jourde, 'Constructing Representations of the "Global War on Terror"

${ }^{34}$ Democratic Coalition Project, 'Burkina Faso

(http://www.demcoalition.org/pdf/6_Burkina_Faso.pdf).
} 
Presidents Wade, ATT, and Compaoré talked about wanting to address the remaining economic challenges with the vigor they have attacked poverty in their first terms.

An exception to this incumbent stranglehold over development or security issues comes when the personal biography of an opposition leader demonstrates expertise in particular issue area. As leaders of the opposition, Wade and Konare used their experience as teachers to mobilize student voters in the 1990s. In 2006, political neophyte Yayi Boni was elected President of Benin. Boni, who holds a PhD in Economics, was able to defeat a political insider by running a campaign focused on economic reform. Of course, this personalization of party platforms points to the weakness of political parties - especially when people like Boni chose to run as independents, but this strategy may offer an entry point for parties to build subsequent issue reputations.

\section{Contentious Issues}

We define contentious issues as those that resonate deeply with citizens, but are largely unclaimed by either the opposition or the incumbent parties because they fall outside of the realm of imagined politics of westernized elites, or are viewed as risky for elite actors to pursue given the views of the donor community; as a result, these issues have been poorly captured by political parties.

Islam, traditional authority, and the family: Negotiation between the secular state and societies that are $90 \%$ Muslim has been complex, not least because of a relative strengthening of Islamic faith and public presence in recent years. ${ }^{35}$ While political parties tend to exclude themselves from these conversations or join them very gingerly, both religious associations and rights-based organizations have eagerly entered the fray, suggesting that citizens are passionate about these issues.

Politicians in the region use their "Muslim" identity on as a reputation-building tool, but rarely does it align with policy concerns. Parties fail to capture the preferences of millions of citizens for a lower marriage age or the legalization of religious marriage. Our earlier anecdote demonstrated popular resistance to the passage of the Family Code which has proved to be one of the most contentious and debated political issues in the region. Women's associations and religious groups have also exchanged in a vociferous debate about the code in Senegal, Benin, and Niger. ${ }^{36}$

The absence of political parties from debates about the code remains striking. Donor and NGO circles have been surprised by the depth and intensity of the opposition to the proposed family code, which they sometimes deride as obscurantist. Resistance to the code, though often shrouded in religious language, embodies a larger political struggle between the state and traditional practices. For example, the most contentious issue in

\footnotetext{
${ }^{35}$ Miles, Political Islam in West Africa; Villalon, 'From Argument to Negotiation'

${ }^{36}$ Wing 'Women's Rights'
} 
the Malian code is the refusal to legalize religious marriage, which has practical implications for the many Malians who forgo or delay an ostentatious "mayor's wedding" due to the prohibitive costs and the clerics who perform these ceremonies. In sum, the proposed changes are widely viewed unsympathetic to the realities of Malian society.

The Role of the State in the Economy: The proper role of the state in the economy is another recurring issue in Francophone West Africa that often proves problematic for parties. Popular debates about the privatization of nationalized industries in all the countries of the region have, for instance, been heated within civil society, and yet little debated within the national legislatures. The privatization of the Mali-Senegal rail line in 2003 incited public protest in both Mali and Senegal. The new owners limited passenger service, cut wages and jobs, and attempted to curb union activity. ${ }^{37}$ As ownership of the Transrail passed through different hands, the railway has severely degraded; following a series of derailments in spring 2009, Transrail ended passenger service from Bamako to Dakar.

Only after Senegalese unions publicized the government's weakness in the face of Transrail did political parties incorporate railway development plans in their platforms. ${ }^{38}$ In Mali, concerned citizens formed an association, Cocidirail, but had little success attracting the ears of political parties. Led by Dr. Tiecoura Traore, who was fired from his job after his vocal opposition to privatization, Cocidirail collected petitions calling for re-nationalization, led protests, and conducted radio sensitization campaigns without gaining the audience of political parties or state officials. ${ }^{39}$ Given the legacy of activism and politics along the rail and the near complete electoral defeat of incumbent deputies from constituencies along the railroad in 2007, it is striking that political parties would not tap into this movement.

More generally, the Transrail experience in Mali and Senegal has tainted the public's opinion of "privatization." ${ }^{40}$ Its unpopularity has helped slow down the privatization of other Malian para-statals, including the national cotton company (CMDT). With the exception of marginal opposition parties, most political parties have remained silent on this issue. In 2003, the presidents of Mali and Burkina Faso wrote a New York Times editorial on the plight of African farmers competing against of Western agricultural subsidies; they joined the government of Benin to lobby the World Trade Organization to form a subcommittee on the issue. ${ }^{41}$ Despite being the importance of the sector to citizens' livelihoods, most political parties have not presented policy positions or prescriptions for the ailing sector.

${ }^{37}$ Munié, 'The Slow Train to Senegal'

${ }^{38}$ Ibid.

${ }^{39}$ Bleck Interview with Tiecoura Traore, November 2009

${ }^{40}$ Privatization battles with the World Bank were further publicized in the Sissako's 2007 film

"Bamako"

${ }^{41}$ 'Your Farm Subsidies Are Strangling Us,' New York Times: July 11, 2003 (17). 
A related issue that arouses a similar sense of economic nationalism in the public concerns the management of natural resources. Debate in Mauritania has focused on EU fishing in Mauritanian waters, while a debate in Niger has focused on the appropriate management of uranium resources (a major grievance of Tuareg rebels) and now of oil extraction; in Mali, a longstanding grassroots movement has questioned the nature of the management of the gold mining sector. Again, however, most political party rhetoric fails to address these issues in a concrete way in recent elections.

Immigration: Immigration is similarly hotly debated in the local press as thousands of young people from the region migrate looking for a better economic future. NGOs create projects and hold conferences to address the root causes of immigration; rappers sing about undocumented immigrants' plights, but political parties have been slow to embrace questions of immigration policy and the rights for undocumented nationals abroad in Europe and the United States. Parties talk about communities abroad in vague terms of solidarity with "returned sons," but rarely take a stand on immigration policy.

The number of readmission treaties between West African and recipient countries have steadily grown over the last decade. As executives attempt to gently negotiate immigration policy, opposition parties miss an opportunity to publicize alternative policy positions. Remittance flows are critically important to the economies of Senegal and Mali; it is surprising that a political party does not emerge with a stronger stance on readmission treaties or treatment of citizens living abroad.

On each of these issues, parties have taken a back seat to civil society actors. Why have parties not tried to own these issues? We hypothesize that political parties have failed to comprehend the potential electoral benefits from mobilizing voters on these issues largely because the values and concerns of westernized elites permeate the leaderships of the major political parties, and they have largely adopted the world view of the donor and NGO community, for whom these issues elicit little controversy

\section{Possibilities for Political issues in Africa}

We have offered a tentative explanation for the puzzling pusillanimity of parties regarding issues for which a more proactive stance could be assumed to have reaped electoral dividends. Legal restrictions probably partly hamper the emergence of more trenchant party rhetoric regarding Islamic issues, but no such restrictions exist for economic policy issues, for instance, other than those that are self-imposed. The primary obstacle for opposition parties is their inexperience, similar backgrounds, and undefined constituencies, which make it difficult for parties to create unique identities as "issue owners." This offers hope for the evolution of parties in Africa. The discussion of certain contentious issues, such as privatization and traditional values, may require the immergence of political actors from different backgrounds with non-Western 
backing. On other issues, future elections may provide parties with more experience with which to create reputations on substantive issues.

Issue ownership is hardly static and unchanging, and in this section we want to briefly hypothesize about the sources of variation, both across countries and across time. First, the countries on which this article has focused share a relatively low level of economic development, with very low levels of national income, low levels of human development, high aid-dependence, and large proportions of rural populations. Even in the context of West Africa, they may prove to be laggards in the process of issue ownership and party institutionalization. For instance, the party system in Ghana appears to be institutionalizing faster than those analyzed in this paper, and observers applauded the emergence of substantive discussions of policy issues, including the firstever televised presidential debates, during the 2008 election in Ghana. ${ }^{42}$ Future research should explore cross-national variation. The experience of multi-party electoral politics in Francophone West Africa is recent, with the partial exception of Senegal. In older political systems, the process of party institutionalization may be further along, and with it the dynamics of issue ownership different than those described here. In richer, bigger economic systems, the weight of the donors is likely to be less significant.

The fledgling nature of party politics in the region suggests that patterns are not fully set. As parties gain experience and as elections bring about alternation, they are likely to establish reputations regarding issues, changing the current patterns of issue ownership. This process will vary across the countries in our sample, even holding structural factors constant, as a function of contingent factors such as the differences in electoral results, the quality of candidates, and the organizational skills of individual parties.

Lastly, by studying predominantly Muslim countries with Francophone institutional and secularist legacies, we fail to engage with important questions about the intersection between Christianity and political parties, which are likely to be significant in other parts of the African continent. The organizational resources of the different Christian churches, as well as their role in various social services, predispose them to a larger political role. Moreover, our hypotheses suggests that identities around regional, ethnic, or religious issues may be the easiest for parties to cultivate in the short term, as long as these issues do not conflict with electoral laws or predominant "elite culture." Given the short life span of most political parties in Africa, it is unsurprising that opposition parties turn to particularistic identities because they are the easiest to own. This does not preclude possibilities for building reputations on substantive issues over time.

42 "Ghana's Historic Presidential Debates": http://www.cipe.org/blog/?p=1274 


\section{References}

Banégas, R. 'Marchandisation du vote, citoyenneté et consolidation démocratique au Bénin'. Politique Africaine 69 (1998): 75-87.

Basedau, M., G. Erdmann, and A. Mehler, eds. Votes, Money and Violence. Scottsville: University of Kwazulu-Natal Press, 2007.

Basedau, M. and Moroff A. 'Promoting Peace and Democracy through Party Regulation? Ethnic Party Bans in Africa'. Presented at annual meeting of Midwest Political Science Association, Chicago, April 2, 2009.

Bayart, J.F. 'Africa in the World: a History of Extraversion'. African Affairs 99 (2000): 217-67.

Baudais, V. and G. Chauzal. 'Les partis politiques et l'indépendance partisane d'Amadou Toumani Touré'. Politique Africaine 104 (2006): 61-80.

Bierschenk, T. 'The local appropriation of democracy: an analysis of the municipal elections in Parakou, Republic of Benin, 2002-03'. The Journal of Modern African Studies 44 (2006): 543-571.

Bogaards, M. 'Ethnic Party Bans in Africa'. Presented to the annual meeting of the International Studies Association, San Francisco, March 26-29, 2008.

Bogaards, M. 'Electoral Systems, Party Systems and Ethnicity in Africa.' In Votes, Money and Violence, eds Basedau et al, 168-93. Scottsville: University of Kwazulu-Natal Press, 2007.

Bratton, M. 'Vote buying and violence in Nigerian election campaigns'. Electoral Studies 27 (2008): 621-632.

Bratton, M. and M.S. Kimenyi. 'Voting in Kenya: Putting Ethnicity in Perspective'. Economics Working Papers 200809: http://digitalcommons.uconn.edu/econ_wpapers/200809.

Bratton, M., R. Mattes, and E. Gyimah-Boadi. Public Opinion, Market Reform, and Democratization in Africa. Cambridge: Cambridge University Press, 2005.

Buijtenhuijs, R. 'Les Partis Politiques Africains ont-ils des Projets de Société? L'Exemple du Tchad'. Politique Africaine 56 (December 1994) : 119-136.

Chabal, P. and J.P. Daloz. Africa Works. (London: James Currey, 1999).

Ciavolella, R. and M. Fresia. 'Entre Démocratisation et coups d'état'. Politique Africaine 114 (2009): 5-23.

Collier, P. Wars, Guns, and Votes: Democracy in Dangerous Places. New York: Harper Collins, 2009.

County, B. Cheminots into Citizens: Labor, Migration, and Political Imagination along the DakarNiger Railroad, 1923-1974. Columbia University, History Department, forthcoming.

Daloz, J.P., ed. Le (Non-)Renouvellement Des Elites en Afrique Subsaharienne. Bordeaux: Centre D'Etude d'Afrique Noire, 1999.

Dalton, R.J. Citizen Politics in Western Democracies: Public Opinion and Political Parties in the United States, Great Britain, West Germany and France. Chatham, NJ: Chatham House Publishers, 1988. 
Dunning, T. and L. Harrison. 'Cross-Cutting Cleavages and Ethnic Voting: An Experimental Study of Cousinage in Mali'. American Political Science Review 104 (2010): 1-19.

Ferree, K. 2006. 'Explaining South Africa's racial Census'. The Journal of Politics 68(2006): 803-815

Erdmann, G. 'Party Research: Western European Bias and the 'African Labyrinth'. Democratization 11 (2004): 63-87.

Gazibo, M. 'Niger's 2004 Presidential Election and Beyond.' In Elections and Democratization in West Africa,1990-2010, Abdoulaye Saine, Mathurin Houngnikpo and Boubacar Ndiaye (Eds.), Trenton, NJ: Africa World Press (forthcoming 2010).

Gazibo, M. "Pour une réhabilitation de l'analyse des partis en Afrique'. Politique Africaine 104 (2006): 5-17.

Glickman, $\mathrm{H}$, ed. Ethnic Conflict and Democratization in Africa. Atlanta: African Studies Association Press, 1995.

Idrissa, A. The Invention of Order: Republican Codes and Islamic Law in Niger.

PhD Dissertation, University of Florida, 2009.

Jourde, C. 'Constructing Representations of the 'Global War on Terror' in the Islamic Republic of Mauritania'. Journal of Contemporary African Studies 25 (2007):78-100.

Jourde, C. 'The International Relations of Small Neoauthoritarian states: Islamism, Warlordism, and the Framing of Stability'. International Studies Quarterly 51(2007): 481-503

Jourde, C. "The President Is Coming to Visit!': Dramas and the Hijack of Democratization in the Islamic Republic of Mauritania'. Comparative Politics 37 (2005): 421-440.

Kuenzi, M. and G. Lambright. 'Party Systems and Democratic Consolidation in Africa's Electoral Regimes'. Party Politics 11 (2005): 423-446.

Lipset, S.M. and S. Rokkan. 'Cleavage Structures, Party Systems, and Voter Alignments: An Introduction'. In Party Systems and Voter Alignements, eds. S.M. Lipset and S. Rokkan, 1-64, New York: Free Press, 1967.

Little, E. and C. Logan. 'The Quality of Democracy and Governance in Africa: New Results from Afrobarometer Round 4'. Afrobarometer Working Paper 108 (2009): www.afrobarometer.org.

Logan, C. 'The Trust Gap'. Afrobarometer Working Paper 108 (2009): www.afrobarometer.org.

Mainwaring, S., and M.S. Shugart, eds. Presidentialism and Democracy in Latin America. New York: Cambridge University Press, 1997.

Marcus, R. and A. Ratsimbaharison. 'Political Parties in Madagascar: Neopatrimonial Tools or Democratic Instruments?' Party Politics 11 (2005): 495- 512.

Mayrargue, C. 'Yayi Boni, Un President Inattendu? Construction de la figure du Candidat et Dynamiques Electorales au Benin'. Politique Africaine 102 (2006): 155-72. 
Miles, William F, ed. Political Islam in West Africa: State-Society Relations Transformed. Boulder: Lynne Rienner Press, 2007.

Mozaffar, S., J.R. Scarritt and G. Galaich. 'Electoral Institutions, Ethnopolitical Cleavages, and Party Systems in Africa's Emerging Democracies'. The American Political Science Review 97 (2003): 379-390.

Munié, Vincent. 'On the Slow Train Trough Senegal'. Le Monde Diplomatique (March 2007).

Norpoth, H. and B. Buchanan. 'Wanted: The Education President: Issue Trespassing by Political Candidates.' Public Opinion Quarterly 56 (1992): 87-99.

Ottaway, M. 'Ethnic Politics in Africa: Change and Continuity'. In State, Conflict and Democracy in Africa, ed. R. Joseph, 299-318. Boulder: Lynne Rienner, 1999.

Petrocik, J. 'Issue Ownership in Presidential Elections, with a 1980 Case Study'. American Journal of Political Science 40 (1996): 825-850.

Petrocik, J.R., W.L. Benoit, and G.J. Hansen. 'Issue Ownership and Presidential Campaigning'. Political Science Quarterly 118 (2003/2004): 599-626.

Rakner, L., and N. van de Walle. 2009. 'Opposition Parties and Incumbent Presidents: The New Dynamics of Electoral Competition in Sub-Saharan Africa'.In Democratization by Elections, ed. S. Lindberg. Baltimore: Johns Hopkins University Press.

Resnick, D. "Political Party Linkages to the Urban Poor in African Democracies", Phd Dissertation, Department of Government, Cornell University, expected 2010.

Saidou, A. 'L'Expérience du dialogue politique au Niger: quel impact sur le système politique.' Working Paper, 2009.

Salih, M., ed. African Political Parties. London: Pluto Press, 2003.

Scottt, A.O. 'World Bank in the Docket, Charged with Africa's Woes.' The New York Times February 14, 2007.

Sears, J.M. Deepening Democracy and Cultural Context in the Republic of Mali,19922002. PhD Dissertation, Queen's University, 2007.

'The State of Democracy in Mali'. Netherlands Institute for Multiparty Democracy, 2009. http://www.nimd.org.

Thiam, A. 'Une Constitution, Ca se révise!' Relativisme Constitutionnel au Sénégal'. Politique Africaine 108 (2007): 145-153.

Van de Walle, N. 'Presidentialism and clientelism in Africa's Emerging Party Systems.' Journal of Modern African Studies 41 (2003): pages.

Van de Walle, N. and K. Butler. 'Political Parties and Party Systems in Africa's Illiberal Democracies'. Cambridge Review of International Affairs 12 (1999): 14-28.

Villalon, L.A. 'From Argument to Negotiation: Constructing Democracy in African Muslim Contexts'. Comparative Politics (forthcoming).

Villalon, L.A. 'Generational Changes, Political Stagnation, and the Evolving Dynamics of Religion and Politics in Senegal'. Africa Today 46 (1999): 129-47.

Villalon, L.A. and A. Idrissa. 'The Tribulations of a Successful Transition: Institutional Dynamics and Elite Rivalry in Mali'. In The Fate of Africa's Democratic 
Experiments, eds. L. Villalon and P. VonDoepp. Bloomington: Indiana University Press, 2005.

Villalon, L. and A. Idrissa. 'Repetitive Breakdowns and a Decade of Experimentation: Institutional Choices and Unstable Democracy in Niger'. In The Fate of Africa's Democratic Experiments, eds. L. Villalon and P. VonDoepp Bloomington: Indiana University Press, 2005.

Wing, S.D. 'Women's Rights and Legal Reform in Francophone Africa'. Presented at 'Rethinking Development: Societal Transformations and the Challenges of Governance in Africa and the Middle East' World Bank Workshop, Yale University, January 30, 2009.

Young, Daniel. 'Is Clientalism at Work in African Elections? A Study of Voting Behavior in Kenya and Zambia.' Afrobarometer Working Paper 106 (2009). 